\title{
CONTROL OF PHYSICAL ASSETS OF BANKING INSTITUTIONS
}

\author{
Ivonne H. Putong, Sintje P. Allouw, Treesje A.C. Langi \\ Department Of Accounting, Polytechnic of Manado Country \\ Rudy A.J. Wowiling \\ Department Of Tourism, Polytechnic of Manado Country \\ DOI: $10.31364 / S C I R J / v 7 . i 12.2019 . P 1219733$ \\ http://dx.doi.org/10.31364/SCIRJ/v7.i12.2019.P1219733
}

\begin{abstract}
Financial institutions that play an important role in a country are banks, because the development and progress of a country will not be separated from banks as financial institutions. As the largest government-owned bank in North Sulawesi and Gorontalo, Bank ABC must also manage fixed assets in order to protect the company's wealth. The purpose of this research was to determine how the internal control of the fixed asset accounting system at ABC Bank. The analytical method used in this discussion is descriptive analysis. The results showed that as a whole was quite effective, the bank's management had applied the principles of internal control over assets and inventory at $\mathrm{ABC}$ Bank. Adequate systems and procedures owned by banks, and supported by the OLIBS (Online Integreted Banking System) system make a significant level of errors in the control and reporting of assets can be resolved quickly. It should be a concern of the management of the placement of human resources to handle office assets and inventory. The system must be supported by reliable employees, and professionals who can carry out the entire procedure in accordance with what has been set.
\end{abstract}

Keywords: Control, Physical Assets, Banking Institutions

\section{Introduction}

Business companies invest their capital in the form of assets that are durable and can support the company's operations, in accounting known as fixed assets. Fixed assets are tangible assets that are obtained in the form of ready-to-use or built in advance, which are used in company operations, are not intended to be sold in the framework of normal company activities and have a useful life of more than one year. Valuation of tangible fixed assets, fixed assets are stated at book value. Book value is the acquisition cost less accumulated depreciation of fixed assets. While the acquisition cost of fixed assets is the money spent or debt incurred and other costs incurred in obtaining fixed assets, from the purchase until the fixed assets are ready for use for company operations. Banks are financial institutions that play an important role in a country, because the development and progress of a country will not be separated from banking institutions as financial institutions. Whatever type of banking, both government and private banking, always requires fixed assets to support its operational activities, as well as Bank ABC. The role of fixed assets is very influential on operational activities. In addition, the role of daily banking activities will not be separated from the financial sector, so it requires a financial report to summarize its financial position.

According to PSAK 16 (revised 2018) "Fixed assets are tangible assets that are owned for use in the production or supply of goods or services to be remitted to other parties, or for administrative purposes; and is expected to be used for more than one period. " Fixed assets have different characteristics from current assets. If current assets are controlled at the time of consumption, control of fixed assets is carried out when planning the acquisition of these assets. This is due to a lot of expenses related to fixed assets, which cannot be done because they are committed costs, which in the lifetime of fixed assets these types of costs cannot be controlled by management through the authority they have (Mulyadi, 2007). Because the control of fixed assets is carried out at the time of the acquisition plan, the fixed asset accounting system provides an authorization mechanism from the time of planning up to the time when the acquisition of fixed assets.

Bank $\mathrm{ABC}$ is a banking institution in the form of a public company. The main activity of Bank $\mathrm{ABC}$ is to raise funds and distribute funds, from and for people who in their operational activities cannot be separated from the use of fixed assets, such as land, buildings used, computers, and so on. From table 1.1 it can be seen the value of the fixed assets of Bank ABC has increased every year. In 2018, the fixed assets value of Bank ABC was IDR 340,356,000,000, an increase from 2016 of IDR 326,101,000,000. 
Table 1.1 Amount of Fixed Assets of Bank ABC

(in millions)

\begin{tabular}{|l|l|l|c|}
\hline Year & 2016 & 2017 & 2018 \\
\hline Fixed Assets & IDR. 326.101 & IDR. 333.679 & IDR. 340.356 \\
\hline $\begin{array}{l}\text { Accumulated } \\
\text { depreciation }\end{array}$ & IDR. 104.364 & IDR. 115.824 & IDR. 120.633 \\
\hline
\end{tabular}

Bank $\mathrm{ABC}$ is a regional financial institution in the form of a bank that is useful to improve the economy of the people in North Sulawesi and Gorontalo and specifically helps the government in carrying out development in the regions of North Sulawesi and Gorontalo. This ABC Bank has 1 head office, and 26 branch offices spread across all regencies and municipalities in North Sulawesi Province, Gorontalo Province, East Java Province, and DKI Jakarta Province. An effective Internal Control System is an important component in Bank management and forms the basis for healthy and safe Bank operations. An effective Internal Control System can assist Bank management in safeguarding Bank assets, ensuring the availability of reliable financial and managerial reporting, increasing the Bank's compliance with applicable laws and regulations, and reducing the risk of losses, irregularities and violations of prudential aspects. The implementation of the Bank's Internal Control System that is reliable and effective, is the responsibility of the Bank's management and officers. In addition, the Bank's management is also obliged to promote an effective risk culture in the Bank's organization and ensure that it is inherent at every level of the organization. The Internal Control System needs to get the attention of the Bank, bearing in mind that one of the factors causing the Bank's business difficulties is the existence of various weaknesses in the implementation of the Bank's Internal Control System. In 2018, the General section found discrepancies in the ABC Bank's fixed assets list. Some fixed assets are valued at $\mathrm{Rp}$. 1. This value is odd because the asset is still in its productive period. Assets are assets of companies that are not prone to fraud by taking into account the total assets of Bank ABC of 340 billion. Based on the existing problems, the researchers conducted research with the topic Control of Physical Assets of Banking Institutions.

\section{Research methods}

The place of this research was the banking institutions owned by the North Sulawesi regional government and Gorontalo, whose business location was in the city of Manado. The object of research, namely the ABC Bank's fixed assets internal control system. To get the data needed, researchers used the following data collection methods:

1. Observation technique is a research conducted by directly observing the company, namely at Bank ABC to obtain relevant data in this research.

2. Interview Technique is research conducted by conducting interviews directly with company leaders and a number of personnel to obtain empirical data.

3. Documentation, which is a method of collecting data with a documentary method, is to trace historical data held by a particular organization. Most of the data in the form of notes, regulatory reports, as well as other written sources relating to the information needed. The data needed in this study are all data related to accounting for fixed assets of the company.

The analytical method used in this discussion is descriptive analysis. This method is used to determine whether or not internal control is applied by comparing related theories then an analysis is carried out in accordance with the theory to interpret it and the extent of the effectiveness of internal control in detecting fraud on ABC's fixed assets.

\section{Discussion}

\section{Company Characteristics}

In addition to operating in the North Sulawesi and Gorontalo regions, Bank $\mathrm{ABC}$ also opened branches in Jakarta and East Java. The ABC Bank office and ATM network, namely:

Table 3.1. Office Networks and ATMs of Bank ABCPosisi 31 Juli 2019

\begin{tabular}{|c|l|c|}
\hline Number. & \multicolumn{1}{|c|}{ Office Network/ ATM } & Amount \\
\hline 1 & Head Office & 1 \\
\hline 2 & Branch Office & 26 \\
\hline 3 & Sub-branch Office & 25 \\
\hline 4 & Cash Office & 63 \\
\hline
\end{tabular}

www.scirj.org

(C) 2019, Scientific Research Journal

http://dx.doi.org/10.31364/SCIRJ/v7.i12.2019.P1219733 


\begin{tabular}{|c|l|c|}
\hline 5 & Mobile Cash Office & 15 \\
\hline 6 & Payment Point & 22 \\
\hline 7 & ATM & 222 \\
\hline 8 & CDM & 2 \\
\hline
\end{tabular}

Source: Researcher's Processed Data

ABC Bank has huge assets and inventory. The balance of the acquisition of assets and company inventory on the balance sheet after the audit as at 31 December 2018 was IDR 366,772,973,125. After deducting the accumulated depreciation of IDR $137,825,196,530$, - the book value of assets and company inventory amounted to IDR 228,947,776,595. The value of these assets has been through the process of asset revaluation carried out by the company in 2016. The value of the assets during the revaluation period was quite significant, namely IDR 148,906,621,267, - from IDR 40,475,248,733 to IDR 189,381,870,000. This asset revaluation advantage helps companies go public to record asset values to more realistic prices, and attract investors. Another advantage of asset revaluation is that it reduces tax liability to be lighter because of the increased depreciation expense.

\section{ABC Bank Internal Control System}

\section{a. Control Environment}

a) Management philosophy and operating style

Based on the results of research according to the personnel section, the management philosophy applied by ABC Bank managers is in accordance with the principles of the COSO (Committee of Sponsoring Organization of The Treadway Commission). In this case the leadership of Bank ABC emphasizes on employees to always obey the rules set by the company. All employees are emphasized to act and be kind to all debtors, employees and other parties associated with the company. In addition, Bank ABC always strives to provide satisfying services to customers.

b) Commitment to integrity and ethical values.

It is important for managers to create an organizational culture that emphasizes integrity and ethical values. Bank $\mathrm{ABC}$ has implemented integrity and ethical values in employees. The integrity and ethical values at ABC Bank uphold honesty in every activity. The honesty in question is the attitude of discipline with high integrity. Honesty is one of the ethics that is maintained at Bank ABC.

c) Commitment to competence

Companies in carrying out the recruitment of employees handled by the personnel, and decided directly by the director. After going through a series of administrative selection, written tests and interviews. At PT. Bank ABC in carrying out recruitment, the company requires a minimum of Strata 1 education for office staff. The company does not see the background of the department of education with the existing work in the company. Weaknesses from management, namely in the placement of employee positions do not always match the educational background. Therefore, Bank ABC provides facilities for the development of resources through education and training for employees in accordance with their duties and responsibilities. This opportunity should be used as well as possible by staff to improve their knowledge and competencies in accordance with the job description of their position.

d) Audit committee and board of directors.

Factors that can affect the effectiveness of the audit committee, and the board of commissioners, including independence from management, and the extent of their involvement in management activities. The Board of Commissioners of Bank $\mathrm{ABC}$ consists of two people who have been formally formed by the Internal Audit Work Unit.

e) Organizational structure

The organizational structure regarding the handling of assets and inventory of companies contained in Bank $\mathrm{ABC}$ is quite good. This organizational structure has clearly demonstrated the division of tasks and authority of each function, so that control can be carried out better. The function of purchasing fixed assets, accounting records until the write-off of assets is carried out by different units.

f) Establishment of authority and responsibility

Separation of functions in the organizational structure at $\mathrm{ABC}$ Bank has also been held. Based on the existing job description the authorities and responsibilities of each position have been determined, making it easy to trace if something goes wrong. Establishment of authority and responsibility at ABC Bank is good.

g) Human resource policies and practices

The policies and practices of human resources implemented at ABC Bank have been going well. This can be evidenced by the existence of guidelines on the provision of financing as a technical guide in the implementation of financing, the provision of Job Training for new and old employees, giving Bank $\mathrm{ABC}$ rewards and punishments are given to employees who excel as a form of appreciation from the company for achieving its targets and good performance. Usually the form of reward given is a promotion and salary bonus.

\section{b. Control Activities}

1. Good document design

2. Separation of duties 
Authorization to approve the purchase of assets and inventory at Bank ABC has separate duties and authorities from the purchase function. Head of Branch who has the authority to approve the purchase of assets and inventory in accordance with nominal limits owned separately from the purchasing function carried out by the General Section and Human Resources. At the head office, authorizing the purchase of assets is with the director, and then it is the duty of the General Division to support the needs of the other sections.

3. Transaction Authorization

All stages and procedures for submitting an application for asset purchase, and inventory are the responsibility of employees of each section, with the approval of the branch leader / director. Control over the authorization of purchasing assets, and inventory has been running well. This can be seen by the existence of limits, officials will not lose their authority and authority during the process of purchasing assets and inventory. Asset procurement within the Bank ABC environment has been determined in accordance with the amount of procurement to be carried out. For procurement of assets under IDR 25 million, can be held by the branch office. If you need assets above IDR 100 million, it requires approval from the Board of Directors.

4. Securing property and company records

The safeguarding of assets and company records is good. At ABC Bank there is a warehouse available as a storage area, and it is locked by the authorized employee after working hours are over. Physical protection of documents and records is sufficient, with the availability of a folder as a place to store documents and then put it in a safe, and only the authorized part can access it. Every workspace has CCTV inside it.

5. Creating an independent check

Checking is done so that in every activity in the company, if there are errors can be easily detected, and corrected immediately. Checks conducted at ABC Bank are good enough, this can be seen from the analysis by each head of the report provided by employees at each part.

\section{c. Risk Assessment}

Risk assessment conducted by $\mathrm{ABC}$ Bank is good enough. Actions taken by Bank $\mathrm{ABC}$ in identifying, analyzing, and assessing the risks that arise in the company, namely directors and officials hold a general meeting to discuss the risks that arise in achieving the company's goals. Companies are quite responsive to the risks that have been determined, and the changes that must be made to be able to compete in this era of globalization, both in terms of regulations, and new standards that must be followed.

\section{d. Information and Communication}

The information and communication available at ABC Bank is good enough. The existence of the OLIBS system at banks makes the accounting system for fixed assets quickly accessible. Evidenced at the time of the occurrence of reports of asset depreciation, and productive inventory worth IDR 1 can be detected as quickly as possible. OLIBS began to be used at ABC Bank since 2000. Rapid economic and banking developments, so this system was updated in 2016. One finding that is a weakness of this system, namely the system was made by Informatics experts, but lacked support from accounting experts.

\section{e. Performance Monitoring}

Performance monitoring in ABC Bank has been scheduled well. Asset report checking and inventory are followed by physical checking which is scheduled to be carried out twice a year, which is matching the number of assets, the existence and condition of the assets. In the event of damage or loss, an Official Report is made. However, in practice this schedule is not fully implemented by the General Section. Ever lost a motorcycle, office inventory is late known.

\section{Conclusion}

As for the conclusions obtained by conducting research on internal control over assets, and inventory on Bank $\mathrm{ABC}$ as a whole is running quite effectively, the bank's management has applied the principles of internal control according to COSO. The system, and adequate procedures owned by the bank and supported by the OLIBS system, make a significant error rate of control, and reporting assets can be resolved quickly. For companies, to pay more attention to the educational background of employees, tailored to the duties and responsibilities. Judging from the number of employees with accounting education, the number of needs is still lacking. The OLIBS system helps a lot in making accounting reports. But in monitoring and evaluation it should be done by an accountant. This is to anticipate errors OLIBS system is not protracted, and immediately corrected by consulting the system maker. It is recommended for other researchers, who will conduct further research of the problems in this study, to be more critical in reading the company's condition in the application of the internal control system for assets. Other companies that face almost the same problems to make improvements, and evaluate the internal control system of assets to be more effective. 


\section{REFERENCES}

Agoes, Sukrisno 2014, Auditing oleh kantor Akuntan Publik, Edisi 5, Lembaga Penerbit, Fakultas Ekonomi Universitas Indonesia, Jakarta.

Baridwan, Zaki, 2008, Intermediate Accounting, Yogyakarta, BPFE

Budiman, E., \& Elim, I. (2016). Analisis Pengendalian Intern Aset Tetap pada PT. Hasjrat Multifinance Cabang Manado. ACCOUNTABILITY, 5(1), 31-42.

Cahyadi, A. I. (2013). Analisis Pengujian Pengendalian Aktiva Tetap dalam Mendeteksi Kehilangan Aktiva Tetap pada Stikes Perdhaki Charitas Palembang.

Darmayanti, Novi. (2016) "The Accounting Treatment of Costs of Acquisition and Depreciation Fixed Assets As Well As The Influence of The Financial Statements." Koordinasi Perguruan Tinggi Swasta (KOPERTIS) Wilayah VII.

Makaluas, J. L., \& Pontoh, W. (2018). Analysis of Internal Control of Fixed Assets in PT. Lumbung Berkat Indonesia. ACCOUNTABILITY, 7(01), 1-10.

Mulyadi, 2017, Accounting System, Jakarta: Salemba Empat.

Prihaningrum, Aldila 2010, Pengendalian Intern Atas Aktiva Tetap Pada PT, Sumberdaya Sewatama persero, Universitas Pembangunan Nasional Veteran, Jakarta.

Putra, T. M. (2013). Analisis penerapan akuntansi aset tetap pada CV. Kombos Manado. Jurnal EMBA: Jurnal Riset Ekonomi, Manajemen, Bisnis dan Akuntansi, 1(3).

Rusmanto, R. (2018). Pengaruh Karakteristik Kualitatif Laporan Keuangan terhadap Penggunaannya dalam Pengambilan Keputusan Kredit Bank Umum di Banjarmasin. EKUITAS: Jurnal Ekonomi dan Keuangan, 12(1), 53-73.

Standar Akuntansi Keuangan, 2017, Dewan Standar Akuntansi Keuangan Ikatan Akuntansi Indonesia.

Warren et al 2010, Introduction of accounting Salemba Empat, Jakarta. 